\title{
TRADE CREDIT: THEORIES AND
}

\section{EVIDENCE}

\begin{abstract}
In addition to borrowing from financial institutions, firms may be financed by their suppliers. Although there are many theories explaining why non-financial firms lend money, there are few comprehensive empirical tests of these theories. This paper attempts to fill the gap. We focus on a sample of small firms whose access to capital markets may be limited. We find evidence that firms use trade credit relatively more when credit from financial institutions is not available. Thus while short term trade credit may be routinely used to minimize transactions costs, medium term borrowing against trade credit is a form of financing of last resort. Suppliers lend to firms no one else lends to because they may have a comparative advantage in getting information about buyers cheaply, they have a better ability to liquidate goods, and they have a greater implicit equity stake in the firm's long term survival. We find some evidence consistent with the use of trade credit as a means of price discrimination. Finally, we find that firms with better access to credit from financial institutions offer more trade credit. This suggests that firms may intermediate between institutional creditors and other firms who have limited access to financial institutions.
\end{abstract}

Mitchell A. Petersen

Kellogg Graduate School of Management Northwestern University

Evanston, IL 60208
Raghuram G. Rajan

Graduate School of Business

University of Chicago

Chicago, IL 60637

and NBER 
Trade credit is the single most important source of short term external finance for firms in the United States. ${ }^{2}$ Why do industrial firms extend trade credit when more specialized financial institutions such as banks could provide finance? There are many theoretical explanations for trade credit: Trade credit may provide access to capital for firms that are unable to raise it through more traditional channels. Suppliers may be better than specialized financial institutions in evaluating and controlling the credit risk of their buyers. If so, trade credit may be a way for firms with better access to credit markets to intermediate finance to firms with less access to credit markets. Alternatively, trade credit may allow suppliers to price discriminate using credit when discrimination directly through prices is not legally permissible. Finally trade credit may be useful in reducing transactions costs or in providing assurances about the quality of the supplier's products. Unfortunately, there is very little systematic evidence about why trade credit is extended or which firms are the largest providers or users of trade credit. In this paper, we shed some light on these issues.

The problem in testing theories of trade credit thus far has been the paucity of data. Databases like Compustat do not have the detail needed to test the nuances of the various theories that serve to distinguish them. In this paper, we use a more detailed database compiled by the National Survey of Small Business Finance (NSSBF). This data set focuses on small firms, which are more likely to face constraints on their ability to raise capital.

We find that suppliers appear to have some advantage in financing growing firms, especially if their credit quality is suspect. We conjecture three potential reasons for this. First, the evidence suggests these firms may be a source of future business, and suppliers are more willing to provide credit in anticipation of capturing this business. Second, suppliers may obtain the information they need at low cost from product market transactions, and perhaps from other suppliers. The information that suppliers use in monitoring and controlling repayment seems to be different from that used by financial institutions, perhaps because the nature of the credit is very different. Third, suppliers appear to rely on their ability to repossess and sell the goods against which credit has been granted.

The rest of the paper is organized as follows. In section I, we flesh out the empirical implications of

\footnotetext{
${ }^{2}$ Rajan and Zingales (1993) report that accounts payable amounted to $15 \%$ of the assets for a sample of non-financial U.S. firms on Global Vantage while debt in current liabilities accounted for just $7.4 \%$.
} 
what we believe are the most important theoretical explanations of trade credit. In section II, we describe the data. Section III examines the determinants of trade credit granted by a firm, while section IV examines who receives credit. We conclude with a discussion of the results and suggestions for future research.

\section{Trade Credit: Theories.}

We start with a brief description of the theories that have been proposed to explain the existence and use of trade credit. This list is not meant to be comprehensive. Rather, it reflects what we believe are the more plausible theories in the literature and the ones upon which our data can shed light.

\section{A. Financing advantage theories of trade credit.}

The supplier may have an advantage over traditional lenders in investigating the credit worthiness of his clients, as well as a better ability to monitor and force repayment of the credit. This may give him a cost advantage over financial institutions in offering credit to a buyer (see Schwartz (1974) for an early exposition of the financing advantage theory of trade credit). There are at least three sources of cost advantage.

\section{Advantage in information acquisition.}

The supplier may visit the buyer's premises more often than financial institutions would. The size and timing of the buyer's orders also give him an idea of the condition of the buyer's business. The buyer's inability to take advantage of early payment discounts may serve as a tripwire to alert the supplier of a deterioration in the buyer's creditworthiness. ${ }^{3}$ While financial institutions may also collect similar information, the supplier may be able to get it faster and at lower cost because it is obtained in the normal course of business.

\section{Advantage in controlling the buyer.}

It may be in the nature of the goods being supplied that there are few economical alternative sources other than the supplier. If so, the supplier can threaten to cut off future supplies in the event of borrower actions that reduce the chances of repayment. This threat may be especially credible if the buyer accounts for a small portion of the supplier's sales. By contrast, a financial institution may have more limited powers; the threat to withdraw future finance may have little immediate effect on the borrower's operations. Furthermore,

\footnotetext{
${ }^{3}$ Theories of trade credit based on the seller having superior information to financial institutions, or the seller using trade credit terms to sort buyers include Brennan, Maksimovic and Zechner (1988), Smith (1987), Biais, Gollier, and Viala (1993).
} 
the financial institution's ability to withdraw past finance may be constrained by bankruptcy laws.

\section{Advantage in salvaging value from existing assets.}

If the buyer defaults, the supplier can seize the goods that are supplied. The more durable the goods supplied, the better collateral they provide and the greater the credit the supplier can provide (see Mian and Smith (1992)). Financial institutions can also reclaim the firm's assets to pay off the firm's loan. However, if the supplier already has a network for selling its goods, its costs of repossessing and resale will be lower than that of an institution. The advantage of suppliers over financial institutions will vary cross sectionally depending upon the type of goods the supplier is selling and how much the customer transforms them. The less the goods are transformed by the buyer the greater the advantage the supplier will have over financial institutions in finding an alternative buyer. ${ }^{4}$

\section{B. Price discrimination through trade credit.}

Trade credit may be offered even if the supplier does not have a financing advantage over financial institutions because credit may be used to price discriminate. ${ }^{5}$ Since credit terms are usually invariant to the credit quality of the buyer, trade credit reduces the effective price to low quality borrowers. ${ }^{6}$ If this is the most price elastic segment of the market, then trade credit is an effective means of price discrimination. A natural reason why this segment's demand may be more price elastic is because it is typically credit rationed. If so, trade credit both lowers the effective price of the good and permits this segment to express its demand.

Another way of seeing this is to note that firms with a high margin (between sales and variable costs) for their product clearly have a strong incentive to make additional sales, but without cutting the price to existing customers. Since their profit on the next unit is higher, they would be willing to incur a positive cost to sell an additional unit, so long as it does not affect their previous sales. Under the assumption that anti-trust

\footnotetext{
${ }^{4}$ Of course, if there are multiple creditors including financial institutions, bankruptcy laws may prevent a creditor from seizing particular goods unless the sale is on consignment, in which case this advantage may be irrelevant.

${ }^{5}$ See Meltzer(1960), Schwartz and Whitcomb (1979), Brennan, Maksimovic and Zechner (1988), and Mian and Smith (1992).

${ }^{6}$ Petersen and Rajan (1994) find that once the decision to grant credit has been taken, the credit terms seem to follow industry practice. They are usually not tailored to the particular borrower. Also see Smith (1980).
} 
laws prevent direct price discrimination, high priced trade credit may be a subsidy targeted at risky customers. Creditworthy customers will find the trade credit overpriced and repay it as soon as possible. On the other hand, risky customers will find it worthwhile to borrow because trade credit may still be cheaper than the other sources they have access to.

A related version of this theory is that the supplier does not discriminate in favor of the risky customer solely because the customer's demand is more elastic in the short run. Rather, the supplier may have a long term interest in the survival of the customer firm. This is especially true if the supplier has no potential substitutes for the customer. The supplier then factors in not only the net profit margin on current sales but also the present value of the profit margins on future sales when deciding whether to help the customer with credit. In other words, the supplier may want to protect the value of its implicit equity stake in the customer by providing it temporary short term financing.?

\section{Transactions costs theories.}

Trade credit may reduce the transactions costs of paying bills (Ferris, 1981). Rather than paying bills every time goods are delivered, a buyer might want to cumulate obligations and pay them only monthly or quarterly. This will also enable an organization to separate the payment cycle from the delivery schedule. There are other versions of the transactions cost theory. There may be strong seasonalities in consumption patterns for a firm's products. In order to maintain smooth production cycles, the firm may have to build up large inventories. This has two costs - the costs of warehousing the inventory and the costs of financing it. Of course, the firm could lower prices in order to effect early sales. But there may be menu costs in doing this, as well as a loss in discretionary ability. By offering trade credit selectively, both across customers and over time, the firm may be able to manage its inventory position better ${ }^{8}$ The firm can thus reduce warehousing costs, especially if its customers have a better ability to carry inventory.

\section{Data and Econometric Model.}

\footnotetext{
${ }^{7}$ This argument is conceptually the same as made in Petersen and Rajan (1995). In that model, banks in monopolistic credit markets were willing to subsidize borrowers with low interest rates since they expected to reap a return in the future by charging above market rates to the firms which survived.

${ }^{8}$ See for example the classic Harvard Business School case, Harrington Corporation. Also see Emery (1987).
} 
The above theories are hard to test without detailed firm level data. Fortunately, the National Survey of Small Business Finances which we use contains detailed cross-sectional information on small firms. While these firms are much smaller than the typical firm on a database such as Compustat, some of the above theories are most applicable to small firms. A shortcoming of this survey is that with the exception of sales figures, all other data are available for only one year. This will limit the scope of our investigation. For instance, many of the testable implications of the transactions cost hypotheses pertain to the time series. To the extent that we do not have the data to test these theories, they should be considered part of the null.

\section{A. Sample Description.}

The National Survey of Small Business Finances was conducted in 1988-89 under the guidance of the Board of Governors of the Federal Reserve System and the US Small Business Administration. It targeted nonfinancial, non-farm small businesses which were in operation as of December, $1987 .{ }^{9}$ Financial data were collected only for this fiscal year. The sample was stratified by census region (Northeast, North Central, South, and West), urban/rural location (whether the firm was located in a Metropolitan Statistical Area (MSA)), and by employment size (less than 50 employees, 50-100 employees, more than 100 employees and less than 500 employees (the maximum size in the sample)). The stratification was done to insure that large and rural firms are represented in the sample. The response rate was seventy to eighty percent, depending upon the section of the questionnaire considered. ${ }^{10}$

There are 3404 firms in the sample, of which 1875 are corporations (including S corporations) and 1529 are partnerships or sole proprietorships. Nearly 90 percent of these firms are owner managed. 12 percent are majority owned by women and 7 percent by minorities. Nearly 28 percent of the firms in our sample are in the service industry. These firms are the smallest when measured on the basis of the book value of assets. Another 27 percent of the firms are in the retail trade industry. The largest firms on the basis of book assets are the manufacturing firms. Twelve percent of our firms are in the manufacturing industry.

One of the virtues of the NSSBF data is that it contains details that are not normally available in more

\footnotetext{
${ }^{9}$ Firms involved in the agriculture, forestry, and fishing industry; finance and insurance underwriting; or real estate investment trusts were excluded from the survey.

${ }^{10}$ Firms were initially sent a series of work sheets which listed the financial information which the questionnaire would collect. The work sheets were followed by a telephone interview.
} 
commonly used data sets such as Compustat. The data set not only includes information from the firm's balance sheet and income statement, but it is also a rich source of information on the current financing of the firm as well as the history of its interactions with financial institutions (i.e. length of relationships with financial institutions and whether the firm applied and was turned down for a loan in the last year). Firms report all outstanding financial obligations to financial institutions, non-financial firms, and individuals. Thus we know whether the firm has a mortgage, the unused portion of its line of credit (assuming it has one), and the interest rate on the firm's most recent loan. The data set also reports some information about the type of financial institutions providing the firm with capital. For example, we know how long the firm has had a relationship with the financial institution and the services which the institution provides.

\section{B. Econometric Model.}

We will attempt to verify some of the implications of the theories described earlier by examining the determinants of a firm's usage of trade credit. In addition to the standard proxies for trade credit usage, accounts receivable and accounts payable, the NSSBF data provide us with proxies hitherto unavailable on a systematic basis. Even so, the lack of detailed data will necessitate some caution in interpreting the results.

When we view the firm as a supplier, its accounts receivable are a proxy for how much it lends its customers. When we view the firm as a customer, its accounts payable are its borrowing from its supplier. Thus we will examine both sets of trade credit relationships a firm has, and treat the firms in our data set first as lenders (suppliers) and then borrowers (customers).

Although we refer to the level of the firm's accounts receivable as a proxy for how much it decides to lend, the level is not determined solely by the firm. Rather, it is a combination of the firm's willingness and ability to extend credit as well as the ability or desire of its customers to repay the amount when due. The former could be thought of as the supply of credit by the firm and the latter as the demand for credit by the customer (See Figure 1). We could therefore specify the trade credit relationship as:

$$
\begin{aligned}
Q_{\text {Demand for Credin }} & =\alpha_{D} \text { Price }_{\text {Trade credit }}+\beta_{D} \text { Demand factors }+\epsilon_{D} \\
Q_{\text {Supply of Credit }} & =\alpha_{S} \text { Price }_{\text {Trade credit }}+\beta_{S} \text { Supply factors }+\epsilon_{S}
\end{aligned}
$$

In this system, the actual level of credit and equilibrium price of credit are determined simultaneously. 
There are several problems with estimating this system using standard simultaneous equations techniques. First, prior research indicates that this market is not typically cleared by adjustments in price (the interest rate). Effective interest rates on trade credit typically do not appear to vary with the credit quality of customers (see Petersen and Rajan (1994) and Smith (1980)). Rather, the burden of adjustment seems to fall on whether credit is granted at all, and when it is repaid. With the market being cleared by quantity restrictions instead of price the set of equations can be rewritten in its reduced form so that the quantity of credit depends only upon the factors which drive the supply of credit offered and the demand for credit by the customer.

$$
\begin{aligned}
Q_{\text {Demand for Credit }} & =Q_{\text {Supply of Credit }} \\
& =\beta_{S} \text { Supply factors }+\beta_{D} \text { Demand factors }+\mu
\end{aligned}
$$

The second difficulty with estimating equation (1) or (2), is we have data on only one side of the transaction. The amount a firm lends on its accounts receivable should depend upon the finances and operations of the firm as well as its customer (see Figure 1). In the absence of data on the firm's customers, we will explain this decision only with the characteristics of the firm (i.e. the supplier).

Normally, the coefficients on the supply factors will not be consistently estimated when the demand factors are excluded from the regression, except when demand and supply factors are uncorrelated. However, if the firm's customers are generally short of other forms of credit, and the price of trade credit does not vary, the demand for credit would far exceed the firm's willingness to supply it. Therefore, given credit hungry customers and a rigid price, accounts receivables is a good measure of credit supplied. ${ }^{11}$ In this case, equation (2) can be rewritten as:

$$
\mathrm{Q}_{\text {Supply of Credit }}=\beta_{\mathrm{S}} \text { Supply factors }+\mu
$$

We will use this equation in estimating the credit extended by the firms in our sample through their accounts receivable (section $\mathrm{II}$ ). However, since this is still a reduced form equation, and we cannot be certain

\footnotetext{
${ }^{11}$ That some customers stretch out repayment is not a problem because, on average, the supplier should anticipate this. Since accounts receivable represent a supplier's average experience with customers, we are on firm ground.
} 
that the firm's customers are largely credit constrained, caution should be taken when interpreting the results.

The process of estimating the amount of credit taken by our firm is similar, although perhaps more informative (section IV). The level of accounts payable will depend both upon the credit extended to the firm (supply effects) as well as our firm's demand for funds (demand effects). We still do not have information on the firm's suppliers. Even so, given proxies for the quantity of credit supplied and demanded, we may still be able to distinguish demand factors from supply factors. In addition to knowing the firm's accounts payables, we also know the fraction of the firm's annual purchases that are made on account. ${ }^{12}$ To understand why this might be a good proxy for the amount of credit offered, we have to consider credit terms in more detail.

Credit terms typically quote a discount date, a due date, as well as the amount of discount for payment by the discount date. For example, firms in the retail business quote trade credit terms as 2-10 net 30 (Smith (1987)). This means the customer receives a 2 percent discount if their bill is paid within 10 days (the discount date) or they may pay the full amount by day 30 (the due date). These terms imply an escalating schedule of penalties. The customer gets what is effectively an interest free loan till the 10th day. If the customer does not pay by the discount date, but pays on day 30 , it is effectively borrowing over the next 20 days at an annual rate of 43.5 percent. If it does not pay by the due date, additional sanctions may be applied such as eventual cut-off of supplies. These sanctions could raise the effective interest rate even higher.

Since there is no cost to accepting credit (at least until the discount date), the fraction actually purchased on account is relatively close to the fraction that is offered on account, which is the amount of credit voluntarily offered by suppliers. Thus when estimating the amount borrowed from suppliers, we will proceed in two steps. We will first estimate the fraction of goods offered on credit to the firm, based on its characteristics. These estimates can then be used to predict the supply of trade credit to the firm. The second step is to note that the firm's accounts payable are a function both of the supply of trade credit and how long the firm takes to repay the debt. The former is proxied for by the predicted value from the first regression, while the other variables in the regression control for demand factors. Holding the predicted supply of credit constant, greater demand for credit will appear as later payment and thus a higher level of accounts payable by our firm. Whether we are able to distinguish the demand from the supply function is then an empirical

\footnotetext{
${ }^{12}$ We also know the fraction of these credit purchases that have discount terms associated with them.
} 
question which we address below.

C. Data description: The use of trade credit by small and large firms.

It is instructive to compare the use of trade credit by firms in our sample to the use of trade credit by larger firms in the much more widely used Compustat data set. We calculate the accounts payable and account receivable to sales ratios by seven broad industry classifications for both our sample of small firms (NSSBF) and a sample of large firms (Compustat). To reduce differences induced by time we use Compustat data from 1987. The ratios are reported in Table I. Small firms uniformly use less trade credit than the large firms. Firms in the NSSBF have accounts payable equal to only 4.4 percent of their sales whereas for Compustat firms, accounts payable comprise 11.6 percent of their sales. ${ }^{13}$

Not only do the small firms borrow less through trade credit, they also extend less trade credit. The small firm accounts receivable to sales ratio is 7.3 percent versus 18.5 percent for Compustat firms. The difference in medians is similar ( 3.8 percent versus 16.1 percent). The greater use of trade credit by larger firms that is apparent in the aggregate numbers, is also apparent in each of the industries. If small firms are more capital constrained we would expect them to extend less trade credit (smaller accounts receivables), but also borrow more through trade credit (have higher accounts payable). However, their desire to borrow through trade credit may not be matched by suppliers' willingness to lend. An analysis of which effect dominates is best left to the regression analysis. A final observation from Table $I$, is that trade credit is not a net source of finance for most firms -- large or small. Across the sample, trade credit is a net source of financing for about a third of the firms. The retail industry is the one exception. In this industry, trade credit is a net source of funds for over half the firms. The retail sector's low level of accounts receivable may be the result of technological changes that have shortened the time it takes to collect (credit card) receivables. The growth of credit card usage will shrink the accounts receivables for retail firms. Accounts receivable have fallen monotonically as a fraction of sales from 9.4 percent in 1970 to 8.0 percent in 1980 to 7.3 percent in 1987.

${ }^{13}$ These averages are calculated including firms which report zero accounts payable (see Table I). The fraction of firms with zero accounts payable is also reported in the table. Instead of standardizing by sales, we could have standardized by costs of goods sold. Using this standardization, small firms still have significantly lower levels of accounts payable. Accounts payable are 9.0 percent of cost of goods sold for the small firms and 18.9 percent of cost of goods sold for the large firms. 
We now examine the use of trade credit by small firms in greater detail. Even in our sample of small firms, borrowing on, and extension of, trade credit increases with firm size. Table II a shows the median accounts receivable to sales ratio when firms are grouped by industry and size. In all industries, the ratio increases with furm size. The median accounts payable to sales ratio also rises with firm size across industries (see Table II b). Thus within the NSSBF sample, and between the NSSBF and Compustat sample, we find larger firms borrow and extend more trade credit.

The firm's purchases on account will be used as a measure of the credit it is supplied. We define annual credit purchases as the product of cost of goods sold and the fraction of purchases made on credit. We normalize this by the value of assets -- because we want to draw a correspondence to leverage which is usually measured in terms of assets -- and report medians in Table II-c. There appears to be a weak positive relationship between credit purchases and size. Because of the nature of their business, both transportation and service firms make very few purchases, hence their credit purchases are also small.

\section{Who offers credit?}

\section{A. The determinants of accounts receivable.}

We now test how the level of accounts receivable depends on the characteristic of the supplier. All the above theories would predict that firms that are more creditworthy, and have greater observed access to institutional credit should offer more finance. The data confirms this in large measure, though there is some surprising new evidence. The use of trade credit as a means of price discrimination also suggests that the amount of credit offered should increase in the firm's margins. This is supported by the data.

\section{The supplier's access to financing.}

In Table IV, we regress the firm's accounts receivable to sales ratio against proxies for the firm's own access to financing, the firm's characteristics, and its incentive to price discriminate. A summary of the data is reported in Table III. Since the firm's ability to extend credit will depend upon its ability to raise funds in capital markets, we must control for the availability and cost of the firm raising capital. Both firm size and firm age are proxies for the credit worthiness of a firm. Typically, larger firms borrow more even though they have higher cashflows and fewer growth opportunities. This suggests that they are more creditworthy. The age of a firm indicates how long it has survived. It is an important proxy, especially in this sample, for firm 
quality and the firm's reputation with potential lenders. ${ }^{14}$ Both variables should have a significant influence on the amount of credit extended by the firm.

This is indeed the case (see Table IV, column I). A firm with $\$ 670,000$ in assets (the 75 th percentile) extends an additional 3.3 percent more of its sales in the form of accounts receivables as compared to a firm with $\$ 55,000$ in assets (the 25 percentile). The effect is economically large for the median accounts receivable to sales ratio is 3.9 percent (see Table III).

Older firms also extend more credit to their customers. However, the magnitude of the coefficient is smaller. Increasing firm age from zero to 10 years old (the minimum to the median) raises the firm's accounts receivables by 1.4 percent of sales. The problem is we have not allowed for sufficient non-linearity in the relationship. Additional years add significantly to a firm's reputation early in its life, but have little effect later. When we include the square of the log of firm age (see Table IV, column II), both age terms are statistically significant. Accounts receivable first increase with age and eventually fall. Accounts receivable peak when a firm is about 19 years of age. Once correctly specified, the effect of age doubles. When a firm matures from a start-up to a 10 year old firm, the credit it extends through accounts receivable rises by three and a half percent of its sales. However the decrease in accounts receivable with age is not nearly as dramatic. ${ }^{15}$

While the above two variables proxy for the firm's access to external financing, we also have data on the maximum amount that can be drawn on the firm's line of credit (if it has one). This is strongly positively

${ }^{14}$ In addition to being better credit risks themselves, older firms may also know more about their customers. In this case, older firms would face less risk in extending credit to their (long time) customers than younger firms. To test this hypothesis, we can separately control for the firm's age and the firm's age under current management. Only the latter variable is included in Table IV. A firm's age under current management is the empirically important variable in predicting the firm's access to capital (see Petersen and Rajan (1994)). Thus including the age of the firm can act as a proxy for the maximum amount of time the firm may have known its customers. Holding the time under current management constant, increasing the age of the firm lowers the firm's accounts receivable -- which is inconsistent with this alternative hypothesis.

${ }^{15}$ Another explanation of the eventual decline in credit offered with firm age is that the oldest firms in our sample are fundamentally different. Recall that to be in the sample, the firm has to have less than 500 employees. Thus if a firm grew enough, it would not be in our sample. The really old firms are likely to be an adversely selected sample of old firms. Since they may also have higher costs of credit, sample selection and the cost of credit is enough to explain the age effect. We are careful to ensure that the results we highlight hold even when we restrict the sample to firms below 10 years where the effect of this selection bias is likely to be small. 
correlated with the amount of accounts receivable that a firm extends $\left(\beta_{\text {Max Line of Credil }}=0.027, t=4.8\right)$. Interestingly, when we break this amount into the portion that has been drawn down already and the portion that is as yet untapped (regression not reported), the amount that has already been drawn down has an estimated coefficient of 0.028 , while the amount that is unused has an estimated coefficient of 0.017 . Thus the line of credit does appear, in part, to be directly financing accounts receivable. ${ }^{16}$

Surprisingly, net income which is a proxy for internal cash generation is negatively correlated with accounts receivable (see Table IV, column I). We would expect that firms with more internal cash -- higher profits -- would be able to extend more credit to their customers. Conditioning on the other variables, however, profitable firms offer less trade credit. We will offer an explanation of this finding shortly.

\section{Economic shocks.}

Changes in a firm's sales may indicate shocks to the firm's operations and help us explain the coefficient on net profits. We include sales growth multiplied by indicators if positive and negative. Firms which have had positive sales growth offer slightly more receivables $(\beta=0.032, t=3.2)$. The coefficient on positive sales growth is economically small.

Firms which have seen their sales decline, however, find their accounts receivable to sales ratios increase significantly $(\beta=-0.051, t=-6.0)$. A firm whose sales drop by thirty percent (the average change for firms with sales declines), increases its accounts receivable to sales ratio by about three percent of sales. ${ }^{17}$ Given that accounts receivable is short term credit -- the days receivable outstanding is less than 30 days on average -- it is unlikely that the downward stickiness is because credit is offered before the collapse in sales

${ }^{16}$ Analogous to this finding, Calomiris, Himmelberg, and Wachtel (1994) find that firms issuing commercial paper also offer more trade credit. So firms with access to short term financing offer more short term credit. We also include accounts payable (as a measure of trade credit borrowing) and the fraction of purchases made on credit (as a measure of the supply of trade credit). The coefficient estimates are positive and significant $\left(\beta_{\text {Payables }}=0.056, t=5.01, \beta_{\text {Purchases }}=0.0002, t=2.9\right)$. The positive coefficients on payables and credit purchases are consistent with the idea that firms with greater access to financing extend more credit. However, the direction of causality between payables and receivables is debatable.

${ }^{17}$ This does not necessarily imply the level of credit extended increases. Consider a firm whose initial accounts receivable to sales ratio is $7.3 \%$-- the average for firms in our sample. The regression results predict that a fall of 30 percent in the firm's sales is associated with the accounts receivable to sales ratio rising to $8.8 \%$. Therefore, after sales fall by 30 percent, accounts receivable are now $0.103 * 0.700 *$ initial sales, i.e. $6.2 \%$ of initial sales. Accounts receivable have fallen, but only 15 percent. 
and is not yet due. Rather, firms in trouble may use the extension of credit to attempt to maintain their sales. This leads to a possible explanation of why profits are negatively correlated with receivables. When we split profits up into positive profits and losses (Table IV, column (III)), only losses are significantly negatively correlated with accounts receivable $(\beta=-0.10, t=-4.8)$. Thus firms making losses tend to extend more credit.

To explore this further, we separate losses into losses if the firm has positive sales growth and losses if the firm has negative sales growth. The coefficient on the former is almost twice as large $(\beta=-0.126, \mathrm{t}=-$ 4.579) as the latter $(\beta=-0.072, t=-2.289)$. So firms that grow fast (and generate losses in the process) seem to extend more credit and perhaps "buy" sales. But firms in distress (negative sales growth and negative income) also offer more trade credit. Some of the increase in credit extended by distressed firms may be involuntary. It is possible that debtors are less willing to repay a distressed firm. Since repayment is enforced by the threat of cutting off future supplies, such threats are less credible when the supplier is distressed. Also, a distressed firm may be less capable of legal action to recover its dues. The delay in repaying a distressed firm is a potential cost of financial distress that deserves further study. ${ }^{18}$

\section{Price discrimination -- trade credit as a strategic tool.}

Although our focus so far has been on whether a firm has the ability to finance trade credit, our data allow us to test the price discrimination theory. It predicts that trade credit should be positively related to a firm's gross profit margin. The larger a firm's gross profit margin the greater its incentive to sell -- and if necessary -- finance an additional unit. We find a positive relationship (see Table IV, column I) when only the gross profit margin is included $(\beta=0.016, t=2.0)$. The correct specification is once again non-linear (see Table IV, column II). When the gross profit margin squared is included, the coefficient on the linear term rises from 0.016 to $0.060(t=2.1)$ while the coefficient on the squared term is $-0.043(t=-1.7)$. This implies that accounts receivable increase with gross profit margins until they reach about seventy percent. This is about the $90^{\text {th }}$ percentile for gross margins in our sample. The effect is also economically sizeable. An increase in gross margin from zero to 35 percent (the median) increases accounts receivable by about 1.5 percent of

\footnotetext{
${ }^{18}$ We also check that all our prior results are not driven only by distressed firms. We define a firm to be distressed if it has negative sales growth and negative net income. Dropping these firms or dummying them out does not qualitatively affect the coefficient estimates.
} 
assets. $^{19}$

\section{B. Robustness Checks.}

At least part of the pattern of trade credit can be explained by differences in historical practices across industries (see Dun and Bradstreet 1970). To test whether our results are simply picking up historical accident, it is constructive to see whether they survive the inclusion of more detailed industry dummies. In Table IV, column IV we include 40 2-digit SIC dummies. This is the finest classification of industry contained in our data. Not surprisingly, the explanatory power of the regressions rises. However the relationships discussed above are qualitatively unchanged. The economic significance of the gross profit margin is even greater when we control for industry. This is reassuring since gross profit margins differ significantly across industries and could therefore have proxied for unmeasured industry effects.

We have a large number of wholesalers in the sample. This group is further divided into those who sell durables and those who sell non-durables. By restricting the regression to this relatively homogenous group, we can check if the above results hold within group also. As the estimates in column V suggest, this is indeed the case. ${ }^{20}$

We also include an indicator if the firm is located in a Metropolitan Statistical Area (regression not reported). A firm in an MSA extends significantly more credit $(\beta=0.014, t=3.8)$. A potential explanation is that institutional lending is less available in the competitive metropolitan areas (see Petersen and Rajan (1995)), and therefore trade credit substitutes for it. Alternatively, the kind of information trade creditors obtain is less valuable in rural areas where everyone knows everybody else's business. Another possible explanation is that the penalties a creditor can exert on late payers is higher in rural areas, hence credit is repaid more promptly.

\footnotetext{
${ }^{19}$ We have argued earlier that firms with higher cashflow should be able to extend more credit. The gross profit margin is not merely a proxy for cashflow. Net income which is included in the regression is a better proxy. In fact, the correlation between the two is only 0.28 .

${ }^{20}$ This sub sample also enables us to test the "quality guarantee" theory. By this we refer to the argument that trade credit may serve as a warranty for product quality. Firms without reputations in the product market can attest to the quality of their goods by bearing the cost of financing them until such time as the buyer can ascertain quality for himself (see Long, Malitz, and Ravid (1994) and Smith (1987)). This would imply that firms without a good reputation - i.e. smaller and younger firms -- offer more credit and that firms producing durables offer more credit than firms producing perishables. We include an indicator for wholesellers of durables. The quantity of credit offered by these merchants is both statistically and economically insignificantly different from those selling non-durables $(\beta=0.001, t=0.1)$.
} 
To summarize, we find evidence suggesting the cost and availability of finance to the supplier is an important consideration in determining whether credit is extended. This is consistent with any theory of trade credit. We do, however, find that higher gross margins are associated with higher accounts receivable, which is consistent with the price discrimination theory.

What was not predicted by any of the prior theoretical discussion is the greater extension of credit by firms with negative income and negative sales growth. Presumably such firms have higher costs of raising finance. If their extension of credit is voluntary, it suggests a different rationale for trade credit than any of the theories discussed so far. One explanation could be window dressing: managers of distressed firms make sales to low credit quality customers in order to keep the numbers up. Another could be that these firms try (but do not quite succeed) in signaling financial strength: strong firms offer credit and weakening firms attempt to imitate them. ${ }^{21}$ Finally, if the extension is involuntary, it suggests a cost of financial distress little investigated in the literature.

\section{Section IV. Who receives credit?}

We now move on to analyze who receives credit from their suppliers and for how long. This will enable us to better examine the relevance of the financing advantage theory. A firm's stock of accounts payable will depend upon both the amount of credit its suppliers offer as well as the firm's demand for trade credit. We divide our analysis into two steps. We start by examining how much credit the firm's suppliers offer the furm. We conjecture that a firm's creditworthiness should affect how much credit it is offered. But we will also test if factors that give the supplier a greater advantage in financing the firm influence how much credit it is offered.

A. Determinants of who is offered credit : purchases on account.

1. Customer's credit quality.

We know the fraction of purchases that each firm makes on credit. Since the opportunity to purchase on credit and borrow interest free for a few days dominates paying cash, we expect all firms to borrow during

\footnotetext{
${ }^{21} \mathrm{~A}$ related conjecture (we thank David Brown for this) is that financially strong firms with deep pockets set trade credit standards in the industry so that the product-credit package puts financially weaker firms at a disadvantage. Such a conjecture begs the question of why the package cannot be unbundled by the other firms or customers, but suggests interesting avenues for future research.
} 
the initial period. ${ }^{2}$ Thus the firm's purchases on account should be an accurate measure of the credit offered to the firm. Since we do not know what fraction of a firm's cost of goods sold are purchases, we estimate the firm's credit purchases as the fraction of purchases made on credit multiplied by the firm's cost of goods sold. This variable is mismeasured because in addition to purchases, the cost of goods sold includes other items. The most important of these is likely to be wages. ${ }^{23}$ As the survey does not report wages separately, we include employment scaled by assets in our regressions to correct for the inclusion of wages in our dependent variable. As can be seen in Table V, employment is strongly positively correlated with total credit purchases. Having controlled for wages, the remaining variation in the dependent variable should capture the variation in credit purchases from suppliers which is what we are trying to explain.

The firm's credit quality may be especially important in determining whether it is offered credit. The explicit price of trade credit does not appear to vary with the customer's credit quality -- customers in an industry get standard trade credit terms (see Smith (1987)). If suppliers do not use prices -- they do not charge lower quality borrowers a higher explicit price -- then they must use quantity restrictions. We therefore expect higher quality firms to be offered more credit. This is indeed the case. Firms of observably higher credit quality -- as measured by variables such as size and profitability -- receive significantly more credit from their suppliers (see Table V, column I). This effect survives the inclusion of two-digit SIC indicators (Table V, column II).

We have identified at least three aspects of the financing advantage theory: the supplier has better information than financial institutions, the supplier has better control, and the supplier has a better ability to liquidate goods. We can test for each of these aspects.

\section{Relationships with financial institutions.}

\footnotetext{
${ }^{n}$ Few industries offer discounts for immediate cash payment (see Dun and Bradstreet (1970)). Most trade credit is advanced for a specific period of time. For example, payment may be due ten days after the goods are delivered. Other trade credit is offered with a discount if the bill is paid prior to the due date. In either case, the implicit cost of the loan till the discount or due date is effectively zero.

${ }^{23}$ In general, firms do not borrow from their employees. An interesting historical exception can be found in Rogers (1994).
} 
From earlier work (Petersen and Rajan (1994)), we know that relationships with financial institutions appear to increase the availability of finance from financial institutions to the firm. We use the length of the longest relationship with a financial institution to measure how much information, possibly private, the lender has accumulated about the firm. It is also a measure of the firm's reputation in debt markets (Diamond (1989)). If suppliers rely on signals sent by prior relationships with lenders in their decision to offer credit, trade credit offered should increase with the strength of relationships with financial institutions. If, on the other hand, suppliers generate their own information, proxies for relationships with financial institutions should not matter.

A relationship with a financial institution does not increase the trade credit offered to a firm. The effect of relationship length on the supply of trade credit is economically tiny and statistically insignificant $(\beta=-.015$ and $t=-0.2)$. We also include the number of banks from which the firm borrows. A firm that concentrates its borrowing with a single lender will develop a stronger relationship with that lender. The coefficient on the number of banks from which the firm borrows is also small and statistically insignificant (regression estimates not reported). Even whether a firm borrows from a bank at all, a fact easily observable to the firm's trade creditors, has no effect on the supply of trade credit.

The interest rate a financial institution charges its customer should include all credit quality relevant information that the lender can observe and thinks is relevant. Suppliers may look to it as a superior source of information. As a proxy for this information source, as well as an additional measure of credit quality, we include the risk premium (the firm's interest rate relative to a treasury bond of comparable maturity) a firm paid on its most recent loan. Firms which pay higher risk premiums on their most recent loan do receive less credit from suppliers. However, the effect is small and not statistically significant (see Table V, column III). Finally, we include an indicator for firms that have asked for but have been denied credit by financial institutions in the last year. Firms that have been denied their request for a loan in the previous year are offered less on account. The coefficient is not statistically significant. ${ }^{24}$ These results appear to rule out the

\footnotetext{
${ }^{24}$ Firms which report that they were denied a loan request in the last year may not be the best or the worst firms. The best firms are not denied, because they are good credit risks. The lowest quality firms may not bother to apply for a loan which they do not expect to receive. It is only firms of intermediate quality that apply and are turned down for a loan. If this is correct, the proxy is noisy, which would explain why being turned down for a loan has a statistically insignificant effect on the amount of trade credit a firm is offered.
} 
possibility that suppliers rely on banks to monitor on their behalf.

\section{Relationships with suppliers.}

We explore the value to suppliers of investing in future relationships with their customers, by examining the coefficient on profits in Table $\mathrm{V}$ more closely. Recall that suppliers offer more credit to profitable firms. When we estimate separate coefficients for firms making profits and firms making losses, we find the coefficient on negative net profits is negative $(\beta=-.551 \mathrm{t}=-2.3$, regression not reported). So suppliers seem to offer credit to the most profitable and the most unprofitable firms. This suggests that they might have some advantage in lending to lower quality credit risks who might otherwise be shut out off from institutional financing.

Both the financing advantage theory and the price discrimination theory suggest that trade credit should fall off for the lowest quality credits. Why do suppliers seem eager to lend to the most unprofitable firms, when financial institutions are not? As argued earlier, one reason may be that a firm which is currently unprofitable may not remain so in the future. By investing in relationships with currently unprofitable but growing firms, a supplier may capture future profitable business from the firm. ${ }^{25}$ To test this idea, we divide the net profit variable into three categories: firms with positive profits, firms with negative profits but positive sales growth, and firms with negative profits and negative sales growth. The results are reported in column V. The last group are distressed firms, for whom low profits lowers the credit offered by suppliers. ${ }^{26}$ By contrast, growing firms who are currently loosing money get more credit the lower their profits $(\beta=-.844$, $t=3.1$ ). A possible explanation of this is that, first, suppliers have an increasing advantage in lending to poorer quality credits, and second, they do so only if they anticipate that growth in future business will compensate

\footnotetext{
${ }^{25}$ Banks in concentrated capital markets act in a similar way. They extend more credit to young firms than do banks in more competitive capital markets. The banks in concentrated capital markets anticipate correctly that they will be able to recoup their investment by charging higher rates when the firms expand and mature (Petersen and Rajan (1995)). If suppliers have more market power over their customers than banks, they may be able to finance firms which banks can not profitably finance.

${ }^{26}$ The coefficient on net profits for firms with negative profits and negative sales growth is positive, but not statistically different from zero. Neither is it statistically different from the coefficient on net profits for firms with positive profits. Pooling distressed firms with profitable firms has no effect on the explanatory power of the regression.
} 
them for the risks they are taking. ${ }^{27}$ By lending to these apparently high risk firms, suppliers can invest in the future viability and profitability of their customers.

Finally, we include an indicator if the firm is located in an MSA (coefficient not reported). These firms are offered more credit, though the coefficient is not statistically significant.

\section{Liquidation costs.}

The final source of financing advantage is the greater ability of suppliers (relative to financial institutions) to liquidate the firm's assets. Suppliers can repossess and resell goods to other buyers. But once the customer has transformed its inputs into outputs, they will be more costly for the supplier to sell and thus its competitive advantage over financial institutions in liquidating these goods is lost. As a proxy for the supplier's advantage in liquidating the borrower's assets we use the fraction of the firm's inventory that are finished goods. Since the NSSBF does not provide us with information on the composition of each firm's inventory, we use the average finished goods to total inventory ratio for Compustat firms with the same two digit SIC code in 1987. The composition of inventory in an industry has a large effect on the credit that suppliers offer firms in our sample. A firm with only finished goods inventory, compared to zero finished goods inventory, will lower its purchases on account by 73 percentage points $(t=-4.3)$.

To summarize our findings, suppliers do worry about the ability of the borrower to repay. In general, a firm with lower credit quality gets less credit. However suppliers appear to support growing, cashconstrained firms with credit. Not only do the prospects of future profits give them a greater incentive to finance their customers, they may also have a financing advantage over financial institutions. Suppliers seem to use different criteria from financial institutions in assessing whether to offer credit. The availability of trade credit is not significantly related to the existence (or absence) of lending relationships with financial institutions. Finally, the ability of suppliers to liquidate collateral seems important. The lower the ratio of finished goods to inventory, the greater the amount of credit offered. Thus the financing advantage for

\footnotetext{
${ }^{27}$ An alternative explanation is that firms with positive sales growth are more likely in the long run to repay than firms with negative sales growth. While this may indeed be true for long term loans, trade credit is so short term that the growth in sales should have little impact. The probabilities of default may be lower in the group with positive sales growth (though one could argue firms in this group are more likely to be cash constrained). This could explain the higher credit extended to the group with positive sales growth, but not why the credit extended increases as firms become more unprofitable.
} 
suppliers appear to come from their low cost of information acquisition and their ability to more efficiently liquidate assets.

\section{B. Determinants of who demands trade credit: accounts payable.}

1. Supply of trade credit.

Having examined the supply of trade credit, we now turn to the determinants of a firm's demand for trade credit. Once a firm has purchased a good on credit, how long it waits (or can wait) before repaying will determine the level of the firm's accounts payable. An analysis of accounts payable can shed additional light on the financing advantage theory, though it will have no implications for the price discrimination theory.

We explain the firm's stock of accounts payable (normalized by assets) using the predicted supply of trade credit and proxies for the firm's demand for trade credit. We use the estimates from the previous section (Table V, column I) to calculate a predicted value of the purchases on account to assets ratio. Recall that this ratio is mismeasured to the extent that costs of goods sold include wages. We, therefore, subtract from the predicted ratio the firm's employee to assets ratio times the coefficient estimate of 0.200 for the employees to assets ratio estimated in Table $\mathrm{V}$, column $\mathrm{I}^{28}$

The firm's stock of accounts payable increases in our estimate of the purchases that are supplied on account to the firm (see Table VI, column I). The coefficient estimate of 0.027 is economically large and statistically significant. This coefficient implies that an increase in the purchases to assets ratio from 0 to the median of 1.38 increases the firm's stock of accounts payable by about 4 percent of assets.

\section{Demand for funding.}

Conditional on the supply of credit, the amount by which firms stretch their accounts payable should be determined by their demand for credit in general and their demand for trade credit in particular. The variables which proxy for the firm's credit demand include measures of the firm's investment opportunities, asset maturity, liquidity, as well as access to credit from financial institutions.

\footnotetext{
${ }^{28}$ Instead of including an estimate of the supply of trade credit in this regression, we could have included the purchases on account variable from Table $\mathrm{V}$ and then used instrumental variables to estimate the coefficients. This is done in column II of Table VI. In addition to the other variables in the regression (column I), we used employees per thousand dollars of assets, whether the firm was incorporated, and the percent of inventory which is finished goods as instruments. These are the variables which we used in Table V to estimate trade credit supply. The coefficient estimates in column I and II are similar.
} 
Firms that are growing more quickly presumably have more investment opportunities. A proxy for this is the change in sales scaled by assets. The underlying relationship between the demand for trade credit and sales growth is non-linear. Increases in sales raise the firm's demand for credit. Each additional dollar of sales increase the demand for trade credit by 1.2 cents. ${ }^{29}$ To put this number in perspective, a firm's cost of goods sold averages 43 percent of sales in our sample. So firms finance about 3 percent of this with trade credit. However, trade credit is short term credit. If we recalculate this percent based on monthly sales (rather than annual sales) increasing by one dollar, then firms finance about 33 percent of their increased purchases with trade credit. The coefficient on sales declines is negative but small in magnitude $(\beta=-0.004)$. Firms whose sales fall have higher accounts payable, but only slightly more. Combined with the evidence from Table $\mathrm{V}$, this suggests that suppliers are willing to finance high sales growth firms by offering more credit.

In samples of large firms, investment opportunities are typically thought to decline in firm size and firm age. For small firms, it is less clear that this is the case, for certain projects may become viable only after the firm has acquired adequate assets and experience. Our estimates (Table VI, column I) indicate that firm size and firm age are only weakly positively correlated with the firm's accounts payable. The strong positive relationship apparent in Table II between firm size and accounts payable therefore comes mainly from the fact that larger firms are offered more trade credit -- presumably because they are better credit risks -- not because they have greater demand to borrow from their suppliers (see Table V, column I and Table VI, column I).

We also include a crude proxy for whether firms need credit. Firms in the data set report whether they have applied for a loan or line of credit from a financial institution in the past year. Fourteen percent of the furms in our sample have. We find that loan applications are uncorrelated with demand for trade credit. If there are non-trivial costs of applying, the decision to apply may depend upon the firm's expected success in getting a loan. So a number of firms may need credit but may not apply. This may explain why we do not find a

\footnotetext{
${ }^{29}$ For twelve percent of our sample, 1986 sales are not reported. We code the change in sales equal to zero for these firms and include a dummy variable for whether 1986 sales are missing. If these observations are essentially new high growth firms, then we would expect their demand for trade credit to be higher than the trade credit demand from a firm with zero sales growth. We do not find this. Firms with missing sales have slightly lower demand for trade credit than a firm which reports no change in sales. The coefficient on this variable is not statistically significant. Thus coding the firms with missing sales as having zero sales growth is correct on average.
} 
significant correlation.

It is unlikely that a firm will finance long term projects with trade credit. Most firms match the maturity of assets and liabilities, and Diamond (1991) and Hart and Moore (1991) present rationales for this. A measure of a firm's demand for short term financing is its short term assets. ${ }^{30}$ Firms whose assets consist mainly of current assets (excluding cash) demand significantly more trade credit. At the margin, seventeen percent of the firm's current assets are financed by trade credit (see Table VI, column I). Interestingly, cash holdings have no empirical effect (coefficient not reported). ${ }^{31}$

In addition to age and size, we also include dummy variables for each of the two digit industries represented in the data to proxy for differences in industry investment opportunities in Table VI, column III. This increases the magnitude and statistical significance of several of the estimate.

\section{Credit availability.}

Having corrected for the availability of trade credit, the firm's investment opportunities, and the maturity of the firm's assets, we now investigate if the firm's liquidity position and the availability of credit from financial institutions affects the demand for trade credit. If it does in a significant way, this would suggest that trade credit financing is lower in the "pecking order" than internally generated cash (Myers, 1984). The firm's ability to generate cash internally decreases its demand for trade credit. ${ }^{32}$ Each additional dollar of monthly profits lowers the firm's demand for trade credit by 23 cents $(=.019 * 12)$ and the estimate is significant at the $1 \%$ level. The statistically significant and negative coefficient for cashflow in the demand

\footnotetext{
${ }^{30}$ The current assets ratio obviously varies dramatically across industries, ranging from a low of about 20 percent of assets in mining (SIC 1000-1499) and transportation and utilities (SIC 4100-4999) to a high of almost 60 percent in the wholesale trade industry (SIC 5000-5199).

${ }^{31}$ Firms with high cash holdings may have enough cash to not require accounts payable financing, or may have hoarded cash to repay accounts payable. It is not a priori clear which effect should predominate. The estimated coefficient on cash to assets is only $0.026(t=1.1)$.

${ }^{32}$ Theoretically, cashflow rather than profits divided by assets is the correct variable. However, the NSSBF does not report depreciation as a separate expense in the profit and loss statement. We could estimate depreciation as a fixed fraction of the firm's assets and add estimated depreciation to operating profits to get cashflow. However, since we then divide profits (or cashflow) by assets, this would only change the coefficient estimate but not the explanatory power of the regression or the variable. Alternatively we could estimate depreciation as a constant percentage of the firm's property, plant, and equipment. Using a depreciation rate of 10 percent raises the coefficient on cashflow to assets marginally.
} 
equation (see Table VI) and the statistically significant and positive coefficient in the supply equation (see Table V) adds credence to our argument that the firm's purchases on account measures the credit offered to the firm by its suppliers and that we have therefore distinguished the 'supply for trade credit' equation from the 'demand for trade credit' equation.

The firm's demand for trade credit may also depend upon its access to credit from financial institutions. We first examine several explicit measures. Four percent of the firms in our sample report being turned down for a loan or approved for an amount less than they requested. Since we have also included an indicator if the firm applied for a loan, we can distinguish firms that applied and were granted a loan from firms that apply and get less than they demanded. The latter demand more trade credit, although the coefficient is not precisely estimated. As discussed earlier, this may be a biased measure of rationing because creditconstrained furms that do not expect to receive a loan may choose not to apply at all, making the proxy noisy.

The second explicit measure of rationing we consider is the availability of unused lines of credit. Almost one third of the firms in our sample have lines of credit which they have not completely drawn down. We find that firms with larger unused lines of credit demand less trade credit. The coefficient $(-0.063)$ is large (see Table VI, column IV). While firms appear to finance their short term assets with short term liabilities, they appear to treat instiutional finance and trade credit as substitutes. Note that by including only the unused portion of the line of credit, we avoid picking up the accounting identity.

Petersen and Rajan (1994) find that relationships between firms and financial institutions relax credit rationing. If trade credit borrowing comes lower down in the pecking order than borrowing from close financial institutions, we should find that the strength of relationships with institutions is negatively correlated with demand for trade credit. This is exactly what the data show. We use the log of one plus the length of the firm's longest relationship with a financial lender to measure the strength of the lending relationships. Longer relationships with institutions correlate negatively with a firm's demand for trade credit. ${ }^{33}$ An increase in the length of the maximum relationship from zero to ten years (the minimum to the median), lowers a firm's accounts payables by over three percent of its assets. This result implies that trade credit is relied on mainly

${ }^{33}$ The length of the longest relationship is also correlated with the firm's age. The correlation coefficient is 0.55 in our sample. However, the length of the longest relationship is not a proxy for firm age which is included in the regression. 
by firms that are constrained by their institutional lenders. If a firm can secure enough credit from its financial institution, it does not stretch out its accounts payable as long -- suggesting that borrowing from trade creditors, at least for longer periods of time, is a more expensive form of credit. Finally, firms demand slightly more trade credit in MSAs where institutional financing is weaker. Coupled with our observation from Table V that firms in MSAs are offered somewhat more credit, this suggests that trade credit substitutes for institutional finance in more competitive markets.

\section{Price of trade credit.}

Thus far, we have argued that suppliers do not vary the price of trade credit much. But does the demand for trade credit depend on its price? We do not know the specific terms a firm faces, but we do know what fraction of its credit purchases are accompanied by early payment discounts. In our sample, three quarters of the firms report receiving early payment discounts on at least some of their credit purchases. The early payment discount should encourage firms to pay early and thus reduce their accounts payable, holding the supply of credit constant. To test the price elasticity of demand we include the percent of credit purchases offered with early payment discounts. The coefficient is very small and statistically insignificant (see Table VI, column V). This is consistent with the argument that missing early payment discounts is expensive and the decision to take advantage of early payment discounts is driven not by the implicit cost of this credit but instead by whether the firm has alternative source of credit. Only credit constrained firms take advantage of this expensive form of credit. 


\section{Discussion and Conclusion.}

We now attempt to draw reasonable conclusions from all the evidence we have accumulated on the rationale for trade credit. In the absence of confirmatory evidence, some of these conclusions may better be termed conjectures, and await future research.

As might be expected, suppliers offer more credit to firms of higher credit quality. But these firms use less trade credit if they have access to institutional finance. Coupled with the observation that suppliers provide strong incentives for firms not to extend the term of the offered credit by giving substantial discounts for prompt payment and strict penalties for late payment (see Petersen and Rajan (1994)), this suggests that trade credit is more expensive than institutional finance, especially if used for medium term financing.

The desire of suppliers to restrict firms to short term financing suggests an advantage in that type of financing over financial institutions. What is the nature of that advantage? One possibility is that creditors obtain information about the firm routinely, and at low cost, from their transactions with the firm. Of course, financial institutions also produce private information about the firms to whom they lend (Slovin, Sushka, and Polonchek (1993)). Suppliers do not, however, appear to rely on information provided by lending relationships; measures of the strength of institutional relationships or the risk premium on institutional loans granted, have little effect on how much trade credit a firm is offered. A reasonable conclusion from the data is that suppliers collect and use different information than financial institutions. The most valuable aspect of this information may be how current it is. By monitoring repayment and using discounts as a trip-wire, suppliers get a quick read on a firm's financial and economic health (see Smith (1987)).

Suppliers appear to use this informational advantage in lending to firms of currently suspect credit quality (current losses) but with high potential for future business (high sales growth), as well as firms neglected by financial institutions. Why might suppliers continue extending credit to these firms when financial institutions do not? In addition to getting faster information about any deterioration of the firm's prospects, suppliers may continue to have a significant hold over the firm -- so long as it continues production. This is unlike financial institutions whose control may be diminished by bankruptcy filings. Furthermore, suppliers can take added precautions such as making consignment sales when the customer's failure to avail of discounts or pay on time sets off a trip wire. Suppliers are in the best position to liquidate the goods they have sold the 
firm, provided it has not been transformed (and provided they are secured so suppliers can seize the goods). This may be why we find that the supply of trade credit increases in the extent to which inventories consist of raw materials.

In addition to having a greater ability to enforce repayment from risky firms, suppliers may also have greater incentive to offer credit than do financial institutions. When suppliers cannot discriminate by price, trade credit may be necessary to finance sales to those who cannot obtain credit from institutions. A supplier who cannot price discriminate has two margins with which to work -- the price of credit and the price of the good. Thus the supplier's profit margin from a sale enables him to bear a lower profit or a greater loss on the credit than can a financial institution. We find that trade credit offered by a firm increases in the size of its margins on sales. Furthermore, if a firm and its supplier continue to transact in the future, the supplier has an implicit equity stake in the firm equal to the present value of the margins he makes on current and future sales of the product to the firm. This may far exceed the implicit equity stake a financial institution may have because of the potential for future business, and may explain why suspect growing firms tend to be financed by suppliers.

In summary, we find some evidence that suppliers may have a financing advantage, especially when a firm is financially troubled. Also, we have indirect evidence from the correlation between margins and receivables that a firm may offer trade credit as a means of price discrimination. A more direct test of the price discrimination theory would be possible if we knew the set of firms to which a supplier sold. If the set of firms had uniformly high credit ratings, there would be no need to offer credit. If they had uniformly low credit ratings, the supplier could simply lower the price and let financial institutions finance. It is only if buyers come with all manner of credit rating that trade credit becomes a viable instrument of price discrimination. This test awaits more comprehensive data.

The single most important step for future research is to examine the determinants of trade credit over time. This will permit more powerful tests of the financing advantage and transactions costs hypotheses. More detailed data (for instance on the relationships between suppliers and customers) will allow researchers to investigate the price discrimination and quality guarantee hypotheses more fully. The role of financially healthy suppliers in intermediating finance to growing firms as well as the implications for the transmission of 
monetary policy deserves further investigation. Finally, we show that firms with sales declines are forced to extend relatively more trade credit without getting any more support from suppliers. This points to a potential cost of financial distress that has hitherto not been investigated. Furthermore, it suggests that trade credit may be a strategic tool for deep pocket firms to increase the minimum scale of staying in the industry. The scope for research is obvious. 


\section{References}

Biais, Bruno, Gollier, and Viala (1993), "Why do firms use trade credit?", Mimeo, CEPR Conference in San Sebastian.

Brennan, Michael, V. Maksimovic, and Joseph Zechner, 1988, "Vendor Financing," Journal of Finance, 1127-1141.

Calomiris, C., C. Himmelberg, and P. Wachtel, "Commercial Paper, Corporate Finance, and the Business Cycle: A Microeconomic Perspective", NBER working paper 4848.

Diamond, D., 1984, Financial intermediation and delegated monitoring, Review of Economic Studies 51, 393414.

Diamond, D., 1991, Debt Maturity Structure and Liquidity Risk. Quarterly Journal of Economics 56, 709-738.

Dun and Bradstreet, 1970, Handbook of credit terms (Dun and Bradstreet, New York).

Emery, Gary W. 1987, "An Optimal Financial Response to Variable Demand," Journal of Financial and Quantitative Analysis 22, 209-225.

Emery, Gary, 1984, "A Pure Financial Explanation for Trade Credit," Journal of Financial and Quantitative Analysis 19, 271-285.

Ferris, J. S., 1981, "A transactions theory of trade credit use," Quarterly Journal of Economics 94, 243-270.

Hart, O. and J. Moore, 1991, A theory of debt based on the inalienability of human capital, Working paper, MIT.

Lewellen, Wilbur, John McConnell, and Jonathan Scott, 1980, "Capital Market Influences on Trade Credit Policies," Journal of Financial Research 3 105-113.

Long, Michael S., Illen B. Malitz, and S. Abraham Ravid, 1994, "Trade Credit, Quality Guarantees, and Product Marketability, Financial Management 22, 117-127.

Meltzer, Allan H., 1960, "Mercantile Credit, Monetary Policy, and Size of Firms," Review of Economics and Statistics, 42, 429-437.

Mian, S. and Cliff W. Smith, 1992, "Accounts Receivable Management Policy: Theory and Evidence", Journal of Finance, Vol 47, No 1, pp 169-200.

Myers, Stewart C., 1984, The Capital Structure Puzzle, Journal of Finance 39,575-592.

Petersen, Mitchell and Raghuram Rajan, 1994, "The Benefits of Lending Relationships: Evidence from Small Business Data, Journal of Finance 49, 3-37.

Petersen, Mitchell and Raghuram Rajan, 1995, "The Effect of Credit Market Competition on Lending Relationships", Quarterly Journal of Economics 60, 407-444. 
Rajan, Raghuram and Luigi Zingales, 1993, "What do we know about capital structure: Evidence from International Data?", CRSP working paper, University of Chicago.

Rogers, F. Halsey, 1994, "Man to Loan $\$ 1500$ and Serve as Clerk: Trading Jobs for Loans in Mid-NineteenthCentury San Francisco", Joumal of Economic History 54, 34-63.

Schwartz, R.A. and D. Whitcomb, 1979, "The trade credit decision", in J. Bicksler, ed: Handbook of Financial Economics (North Holland Publishing Company).

Schwartz, R. A., 1974, "An Economic Model of Trade Credit," Journal of Financial and Quantitative Analysis, 643-657.

Shleifer, A. and R. Vishny, 1992, Liquidation value and debt capacity: A market equilibrium approach, Journal of Finance, 47, 1343-1366.

Slovin, Myron B., Marie E. Sushka, and John A. Polonchek, 1993, The value of bank durability: borrowers as bank stakeholders, Journal of Finance 48, 247-266.

Smith, K., 1980, Readings on the Management of Working Capital (West Publishing Co).

Smith, Janet, 1987, "Trade Credit and Information Asymmetry," Joumal of Finance, 863-869. 
Table I: Accounts Payables and Receivables to Sales Ratios

Panel A: Small Firms

\begin{tabular}{lcccccc}
\hline & \multicolumn{3}{c}{ Accounts Payable / Sales } & \multicolumn{3}{c}{ Accounts Receivable / Sales } \\
Industry & Mean & Median & \% Zero & Mean & Median & \% Zero \\
\hline Mining & 6.1 & 4.6 & 23.1 & 9.9 & 6.9 & 30.8 \\
Construction & 5.4 & 2.5 & 25.7 & 10.4 & 7.8 & 14.8 \\
Manufacturing & 6.5 & 4.2 & 11.7 & 11.8 & 10.0 & 9.8 \\
Transportation/Utilities & 3.8 & 1.9 & 31.5 & 8.1 & 6.5 & 17.6 \\
Wholesale Trade & 7.0 & 3.8 & 15.6 & 8.1 & 7.0 & 6.2 \\
Retail Trade & 3.9 & 1.7 & 26.6 & 3.0 & 0.4 & 39.6 \\
Services & 2.7 & 0.0 & 51.9 & 8.0 & 3.5 & 34.2 \\
\hline Total & 4.4 & 1.8 & 30.9 & 7.3 & 3.8 & 26.5 \\
\hline
\end{tabular}

This table is based on the National Survey of Small Business Finance. Firms in the agricultural (SIC 100-999) and financial sectors (SIC 6000-6999) were excluded. Ratios are expressed as percents.

Panel B: Large Firms

\begin{tabular}{lrrrrrr}
\hline & \multicolumn{3}{c}{ Accounts Payable / Sales } & \multicolumn{3}{c}{ Accounts Receivable / Sales } \\
Industry & Mean & Median & \% Zero & Mean & Median & \% Zero \\
\hline Mining & 25.2 & 17.5 & 0.5 & 28.7 & 21.7 & 2.0 \\
Construction & 17.0 & 8.3 & 0.0 & 15.8 & 16.4 & 23.7 \\
Manufacturing & 9.8 & 7.4 & 0.4 & 19.1 & 17.0 & 0.6 \\
Transportation/Utilities & 14.3 & 8.6 & 1.2 & 16.2 & 14.1 & 2.6 \\
Wholesale Trade & 12.5 & 8.6 & 2.0 & 15.5 & 14.0 & 0.9 \\
Retail Trade & 8.6 & 6.7 & 0.8 & 7.3 & 2.3 & 6.2 \\
Services & 10.6 & 6.5 & 1.1 & 22.4 & 19.4 & 3.7 \\
\hline Total & 11.6 & 7.6 & 0.7 & 18.5 & 16.1 & 2.3 \\
\hline
\end{tabular}

This table is based on the Compustat data base. Firms in the agricultural (SIC 100-999) and financial sectors (SIC 60006999) were excluded. Ratios are expressed as percents. 


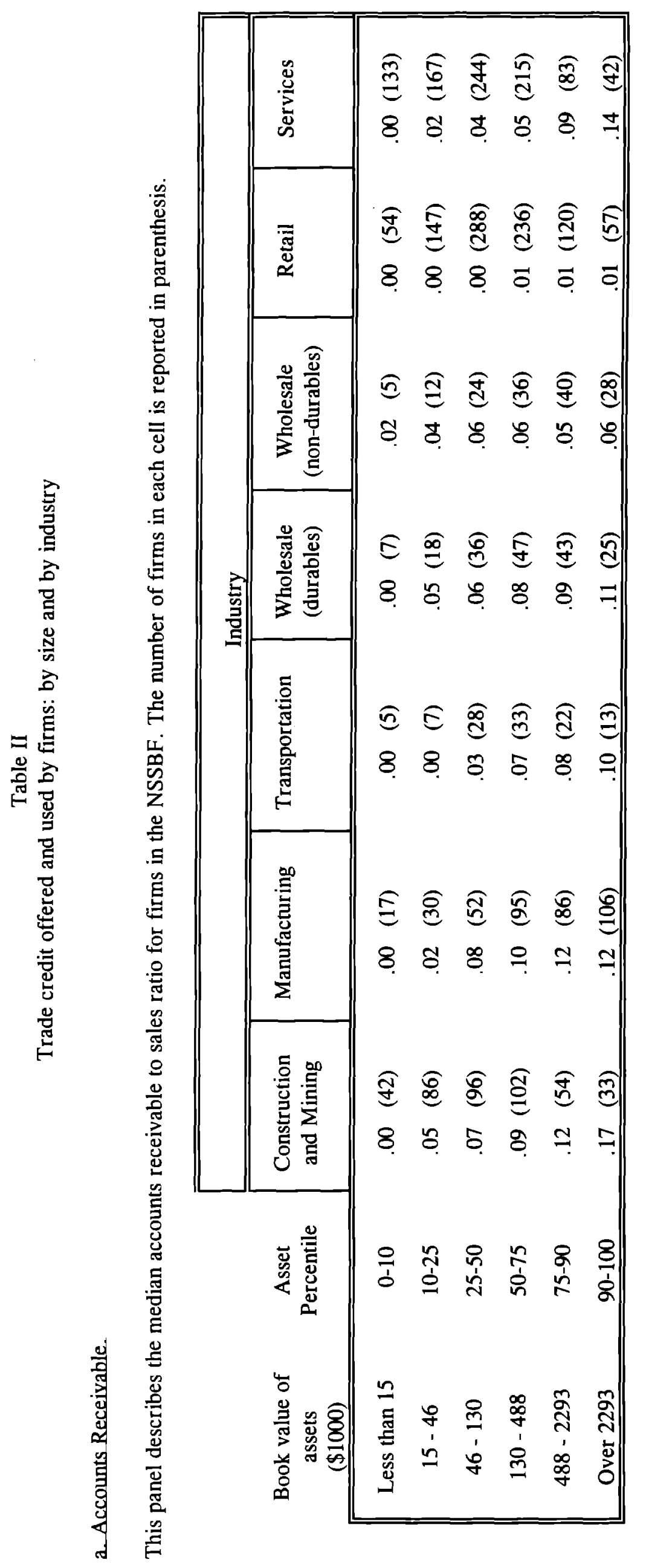




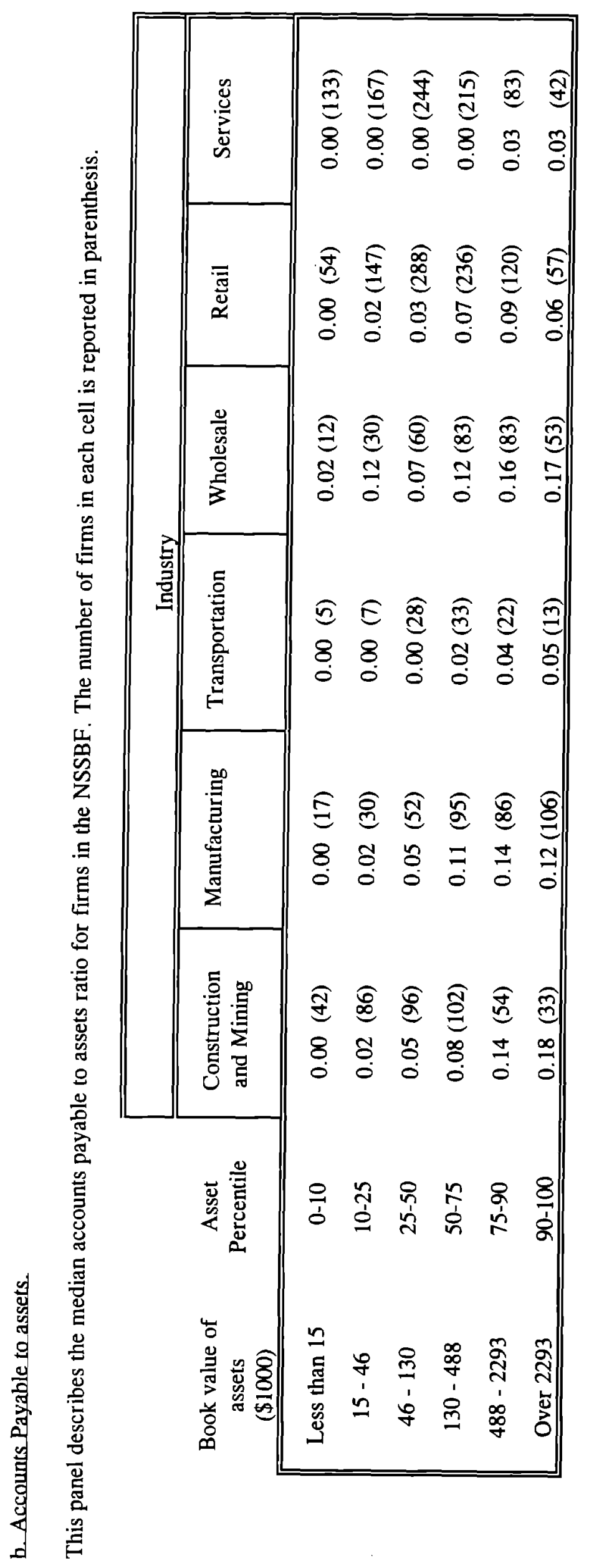




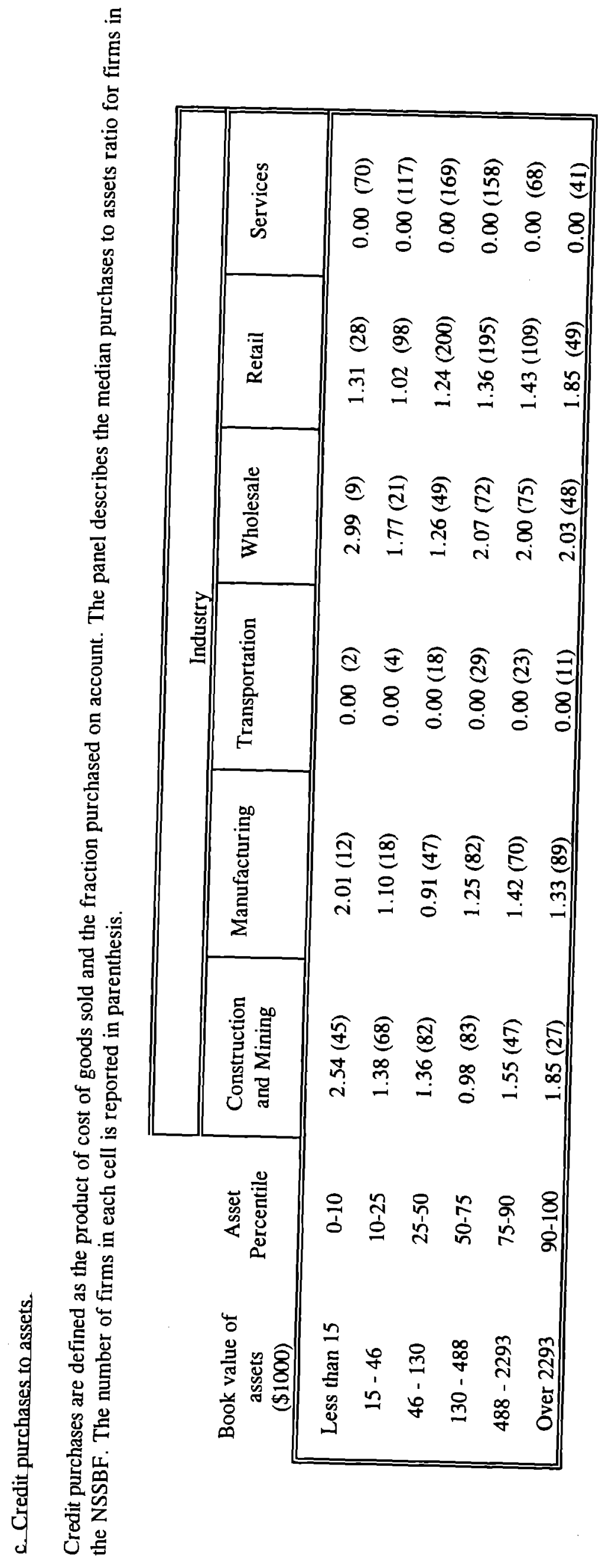


Table III: Summary Statistics.

\begin{tabular}{lccc}
\hline \hline Variables & Mean & Median & $\begin{array}{c}\text { Standard } \\
\text { deviation }\end{array}$ \\
\hline Accounts receivable to sales ratio & 0.066 & 0.039 & 0.083 \\
Log(Book Value of Assets) & 12.18 & 11.96 & 1.93 \\
Log (1 + Firm Age (in years)) & 2.35 & 2.39 & 0.88 \\
$\quad \begin{array}{l}\text { Maximum available line of credit / } \\
\text { sales. }\end{array}$ & 0.06 & 0.00 & 0.09 \\
$\begin{array}{l}\text { Net profit divided by sales. } \\
\text { Percent sales growth (86-87) } \\
\text { if positive, zero otherwise }\end{array}$ & 0.10 & 0.05 & 0.23 \\
$\begin{array}{l}\text { Percent sales growth (86-87) } \\
\text { if negative, zero otherwise }\end{array}$ & 0.26 & 0.07 & 0.59 \\
$\quad$ Gross profits / sales & -0.04 & 0.00 & 0.11 \\
\hline \hline
\end{tabular}


Table IV

The Determinants of Accounts Receivable.

The dependent variable is the accounts receivable to sales ratio reported by the firm. The coefficients are estimated using ordinary least squares. Standard errors are in parentheses. Each regression has a constant whose coefficient is not reported. Firms in the financial industry (SIC 6000-6999) and the service industry (SIC 7000-8999) are excluded unless otherwise stated.

\begin{tabular}{|c|c|c|c|c|c|}
\hline Independent variable & I & II & III & $I V^{a}$ & $\mathrm{~V}^{\mathrm{b}}$ \\
\hline Log(Book Value of Assets) & $\begin{array}{l}.013^{1} \\
(.001)\end{array}$ & $\begin{array}{l}.013^{1} \\
(.001)\end{array}$ & $\begin{array}{r}.014^{1} \\
(.001)\end{array}$ & $\begin{array}{r}.012^{1} \\
(.001)\end{array}$ & $\begin{array}{l}.010^{1} \\
(.003)\end{array}$ \\
\hline $\begin{array}{l}\log (1+\text { Firm Age }) \\
\text { (in years) }\end{array}$ & $\begin{array}{l}.006^{1} \\
(.002)\end{array}$ & $\begin{array}{l}.024^{5} \\
(.010)\end{array}$ & $\begin{array}{r}.025^{1} \\
(.010)\end{array}$ & $\begin{array}{l}.013 \\
(.009)\end{array}$ & $\begin{array}{l}.033 \\
(.021)\end{array}$ \\
\hline $\begin{array}{l}\log (1+\text { Firm Age })^{2} \\
\text { (in years) }\end{array}$ & & $\begin{array}{l}-.004^{10} \\
(.002)\end{array}$ & $\begin{array}{l}-.004^{5} \\
(.002)\end{array}$ & $\begin{array}{l}-.003 \\
(.002)\end{array}$ & $\begin{array}{l}-.007 \\
(.004)\end{array}$ \\
\hline $\begin{array}{l}\text { Maximum available line of credit } \\
\text { /sales. }\end{array}$ & $\begin{array}{l}.027^{1} \\
(.006)\end{array}$ & $\begin{array}{l}.027^{1} \\
(.006)\end{array}$ & $\begin{array}{r}.026^{1} \\
(.006)\end{array}$ & $\begin{array}{l}.021^{1} \\
(.005)\end{array}$ & $\begin{array}{l}.103^{5} \\
(.051)\end{array}$ \\
\hline Net profits / sales. & $\begin{array}{l}-.031^{1} \\
(.010)\end{array}$ & $\begin{array}{l}-.033^{1} \\
(.010)\end{array}$ & & & \\
\hline $\begin{array}{l}\text { Net profits / sales } \\
\text { if positive, zero otherwise. }\end{array}$ & & & $\begin{array}{l}-.004 \\
(.013)\end{array}$ & $\begin{array}{l}-.009 \\
(.012)\end{array}$ & $\begin{array}{l}.023 \\
(.042)\end{array}$ \\
\hline $\begin{array}{l}\text { Net profits / sales } \\
\text { if negative, zero otherwise. }\end{array}$ & & & $\begin{array}{l}-.101^{1} \\
(.021)\end{array}$ & $\begin{array}{l}-.105^{1} \\
(.020)\end{array}$ & $\begin{array}{l}-.153^{1} \\
(.054)\end{array}$ \\
\hline $\begin{array}{l}\text { Percent sales growth }(86-87) \\
\text { if positive, zero otherwise }\end{array}$ & $\begin{array}{l}.032^{1} \\
(.010)\end{array}$ & $\begin{array}{l}.033^{1} \\
(.010)\end{array}$ & $\begin{array}{r}.033^{1} \\
(.010)\end{array}$ & $\begin{array}{l}.004 \\
(.009)\end{array}$ & $\begin{array}{l}-.002 \\
(.027)\end{array}$ \\
\hline $\begin{array}{l}\text { Percent sales growth (86-87) } \\
\text { if negative, zero otherwise }\end{array}$ & $\begin{array}{l}-.051^{1} \\
(.009)\end{array}$ & $\begin{array}{l}-.053^{1} \\
(.009)\end{array}$ & $\begin{array}{l}-.048^{1} \\
(.009)\end{array}$ & $\begin{array}{l}-.030^{1} \\
(.008)\end{array}$ & $\begin{array}{l}-.039 \\
(.028)\end{array}$ \\
\hline Gross profit margin / sales & $\begin{array}{l}.016^{5} \\
(.008)\end{array}$ & $\begin{array}{l}.060^{5} \\
(.028)\end{array}$ & $\begin{array}{l}.056^{5} \\
(.028)\end{array}$ & $\begin{array}{c}.117^{1} \\
(.030)\end{array}$ & $\begin{array}{r}.201^{5} \\
(.079)\end{array}$ \\
\hline (Gross profit margin / sales) $^{2}$ & & $\begin{array}{l}-.043^{10} \\
(.027)\end{array}$ & $\begin{array}{l}-.045^{10} \\
(.026)\end{array}$ & $\begin{array}{l}-.118^{1} \\
(.030)\end{array}$ & $\begin{array}{l}-.206^{5} \\
(.096)\end{array}$ \\
\hline Firm is in MSA $(0,1)$ & $\begin{array}{l}.014^{1} \\
(.004)\end{array}$ & $\begin{array}{l}.014^{1} \\
(.004)\end{array}$ & $\begin{array}{c}.014^{1} \\
(.004)\end{array}$ & $\begin{array}{c}.007^{5} \\
(.003)\end{array}$ & $\begin{array}{l}.012 \\
(.009)\end{array}$ \\
\hline
\end{tabular}


Wholesaler of durable goods $(0,1)$

\begin{tabular}{lccccc}
\hline Number of Observations & 1805 & 1805 & 1805 & 1805 & 277 \\
Adjusted $\mathrm{R}^{2}$ & 0.141 & 0.144 & 0.150 & 0.315 & 0.154 \\
\hline
\end{tabular}

${ }^{a} 402$ digit SIC indicators are included in addition to the constant.

${ }^{b}$ Includes only wholesalers (SIC codes 5000-5199).

When the distribution of a variable was highly skewed for high values, we recoded the highest percent of values to the 99th percentile of the distribution. Similarly if it was highly skewed for low values, we recoded the lowest percent of values to the 1st percentile of the distribution. These variables include accounts receivable to sales, net profits to sales, sales growth, and gross profit margin to sales.

${ }^{1}$ Coefficient significantly different from zero at the one percent level.

${ }^{5}$ Coefficient significantly different from zero at the five percent level.

${ }^{10}$ Coefficient significantly different from zero at the ten percent level. 
Table V

Trade Credit Supply: Purchases Made on Credit over Assets

The dependent variable is the firm's purchases on account divided by assets. Purchases on account is calculated as the percent of purchases made on account times the firm's costs of goods sold. The coefficients are estimated using ordinary least squares. Standard errors are in parentheses. Each regression includes one digit SIC industry dummy variables (unless otherwise specified) and a constant whose coefficients are not reported. Firms in the financial industry (SIC 6000-6999) and service industry (SIC 7000-8999).

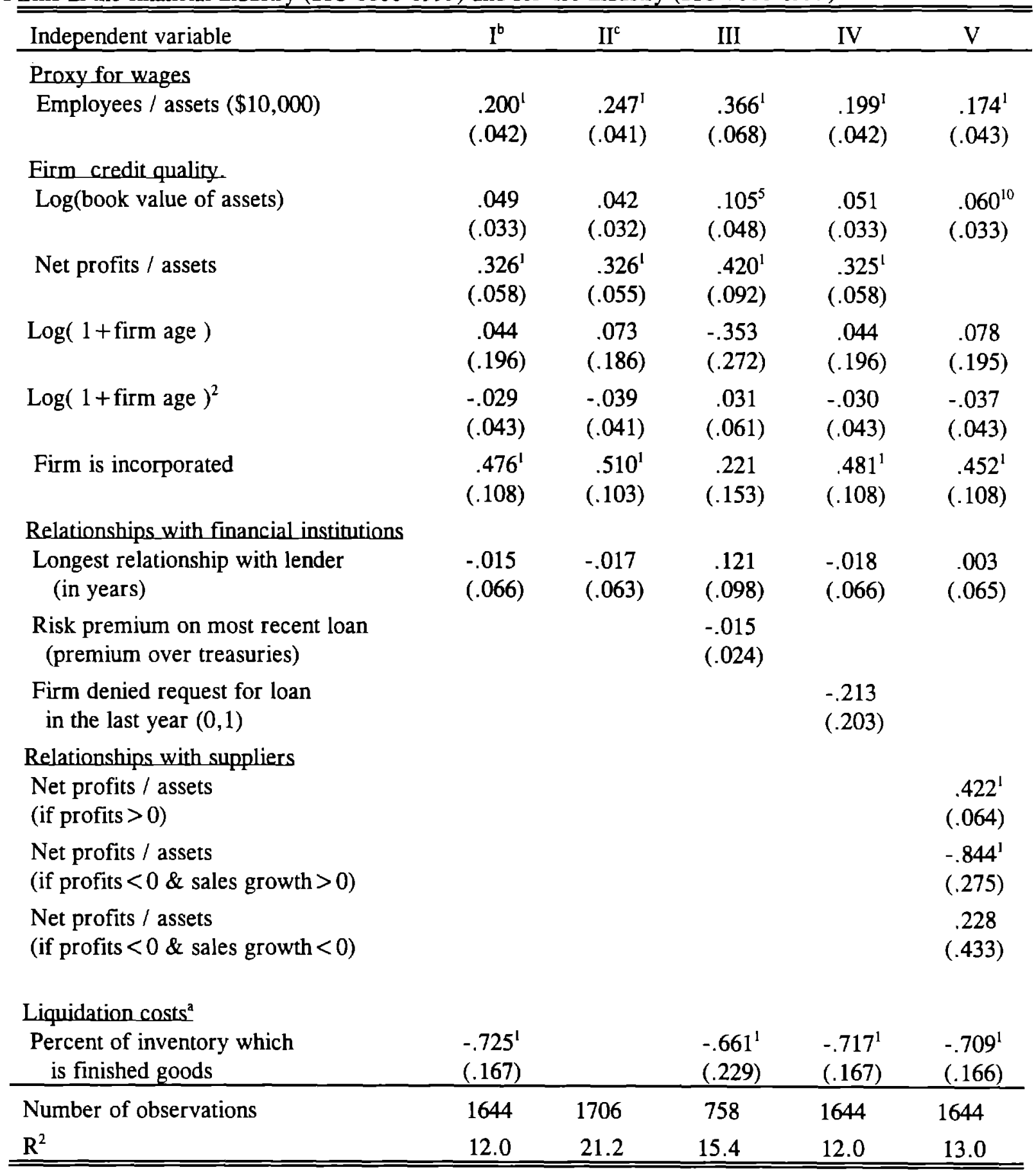


${ }^{a}$ Industry variables are calculated using 1987 Compustat data. Each variable was calculated for firms in a 2 digit SIC code industry. These average industry values were then matched to the firms in the NSSBF.

b Due to low asset values 23 firms had extremely high ratios for purchase on account to assets. These observations were recoded to the 99th percentile of the distribution. We tested this approach by estimating the regression using a tobit with an upper limit of the 99 th percentile of the purchase on account regression. The empirical results are qualitatively similar. Low asset values also caused some of the independent variables to be skewed. When the distribution of a variable was highly skewed, we recoded the upper percent of values to the 99th percentile of the distribution. These variables include operating profits to assets, employees to assets, and number of trade creditors to assets.

${ }^{\mathrm{c}}$ This regression includes 40 industry dummies -- one for each 2 digit SIC code in our data set. The percent of inventory which is finished goods is based on industry averages and must therefore be dropped from this specification.

${ }^{1}$ Coefficient significantly different from zero at the one percent level.

${ }^{5}$ Coefficient significantly different from zero at the five percent level.

${ }^{10}$ Coefficient significantly different from zero at the ten percent level. 
Table VI

Trade Credit Demand: Accounts Payable over Assets

The dependent variable is the accounts payable to asset ratio reported by the firm. The coefficients are estimated using ordinary least squares. Standard errors are in parentheses. Each regression includes five industry dummy variables and a constant whose coefficients are not reported. Firms in the financial industry (SIC 6000-6999) and service industry (SIC 7000-8999).

\begin{tabular}{|c|c|c|c|c|c|}
\hline Independent variable & I & $\mathrm{II}^{\mathrm{b}}$ & III $^{\mathrm{c}}$ & IV & $\mathrm{V}$ \\
\hline $\begin{array}{l}\text { Supply of trade credit } \\
\text { Predicted supply of trade credit } \\
\text { / } \text { assets }^{\mathrm{a}}\end{array}$ & $\begin{array}{r}.027^{5} \\
(.013)\end{array}$ & $\begin{array}{c}.029^{5} \\
(.013)\end{array}$ & $\begin{array}{r}.085^{1} \\
(.019)\end{array}$ & $\begin{array}{c}.027^{5} \\
(.013)\end{array}$ & $\begin{array}{r}.028^{5} \\
(.013)\end{array}$ \\
\hline $\begin{array}{l}\text { Demand for capital } \\
\Delta \text { sales (86-87) / assets } \\
\text { if positive, zero otherwise }\end{array}$ & $\begin{array}{c}.012^{1} \\
(.003)\end{array}$ & $\begin{array}{l}-.001 \\
(.008)\end{array}$ & $\begin{array}{l}.012^{1} \\
(.003)\end{array}$ & $\begin{array}{r}.012^{1} \\
(.003)\end{array}$ & $\begin{array}{r}.012^{1} \\
(.003)\end{array}$ \\
\hline $\begin{array}{l}\Delta \text { sales (86-87) / assets } \\
\text { if negative, zero otherwise }\end{array}$ & $\begin{array}{l}-.004 \\
(.005)\end{array}$ & $\begin{array}{l}.007 \\
(.006)\end{array}$ & $\begin{array}{l}-.002 \\
(.005)\end{array}$ & $\begin{array}{l}-.005 \\
(.005)\end{array}$ & $\begin{array}{l}-.004 \\
(.005)\end{array}$ \\
\hline 1986 sales missing $(0,1)$ & $\begin{array}{l}.002 \\
(.014)\end{array}$ & $\begin{array}{l}-.001 \\
(.017)\end{array}$ & $\begin{array}{l}.002 \\
(.014)\end{array}$ & $\begin{array}{l}.002 \\
(.014)\end{array}$ & $\begin{array}{l}.005 \\
(.014)\end{array}$ \\
\hline $\log$ (book value of assets) & $\begin{array}{l}.005 \\
(.003)\end{array}$ & $\begin{array}{l}.004 \\
(.003)\end{array}$ & $\begin{array}{l}-.002 \\
(.003)\end{array}$ & $\begin{array}{l}.006^{5} \\
(.003)\end{array}$ & $\begin{array}{l}.004 \\
(.003)\end{array}$ \\
\hline $\log (1+$ firm age $)$ & $\begin{array}{c}.029^{10} \\
(.016)\end{array}$ & $\begin{array}{c}.036^{10} \\
(.019)\end{array}$ & $\begin{array}{c}.023 \\
(.017)\end{array}$ & $\begin{array}{c}.029^{10} \\
(.016)\end{array}$ & $\begin{array}{c}.029^{10} \\
(.016)\end{array}$ \\
\hline $\log (1+\text { firm age })^{2}$ & $\begin{array}{l}-.006^{10} \\
(.004)\end{array}$ & $\begin{array}{l}-.006 \\
(.004)\end{array}$ & $\begin{array}{l}-.004 \\
(.004)\end{array}$ & $\begin{array}{l}-.006 \\
(.004)\end{array}$ & $\begin{array}{l}-.006 \\
(.004)\end{array}$ \\
\hline Current assets excluding cash / assets & $\begin{array}{r}.166^{1} \\
(.013)\end{array}$ & $\begin{array}{r}.156^{1} \\
(.018)\end{array}$ & $\begin{array}{r}.168^{1} \\
(.015)\end{array}$ & $\begin{array}{c}.169^{1} \\
(.013)\end{array}$ & $\begin{array}{c}.161^{1} \\
(.013)\end{array}$ \\
\hline $\begin{array}{l}\text { Firm applied for loan during } \\
\text { previous year }(0,1)\end{array}$ & $\begin{array}{l}.002 \\
(.010)\end{array}$ & $\begin{array}{l}.005 \\
(.011)\end{array}$ & $\begin{array}{l}.003 \\
(.010)\end{array}$ & $\begin{array}{l}.003 \\
(.010)\end{array}$ & $\begin{array}{l}.001 \\
(.010)\end{array}$ \\
\hline Credit availability & & & & & \\
\hline Net Profits / assets & $\begin{array}{l}-.019^{1} \\
(.006)\end{array}$ & $\begin{array}{l}-.021^{1} \\
(.007)\end{array}$ & $\begin{array}{l}-.039^{1} \\
(.007)\end{array}$ & $\begin{array}{l}-.019^{\prime} \\
(.006)\end{array}$ & $\begin{array}{l}-.019^{1} \\
(.006)\end{array}$ \\
\hline Available line of credit / assets & & & & $\begin{array}{l}-.063^{1} \\
(.022)\end{array}$ & \\
\hline $\begin{array}{l}\text { Firm denied credit request during } \\
\text { previous year }(0,1)\end{array}$ & $\begin{array}{l}.012 \\
(.017)\end{array}$ & $\begin{array}{l}.019 \\
(.019)\end{array}$ & $\begin{array}{l}.010 \\
(.017)\end{array}$ & $\begin{array}{l}.012 \\
(.017)\end{array}$ & $\begin{array}{l}.012 \\
(.017)\end{array}$ \\
\hline $\begin{array}{l}\log (1+\text { Longest relationship } \\
\text { with lender) (in years) }\end{array}$ & $\begin{array}{l}-.011^{5} \\
(.005)\end{array}$ & $\begin{array}{l}-.018^{1} \\
(.006)\end{array}$ & $\begin{array}{l}-.009^{10} \\
(.005)\end{array}$ & $\begin{array}{l}-.011^{1} \\
(.005)\end{array}$ & $\begin{array}{l}-.013^{1} \\
(.005)\end{array}$ \\
\hline Firm is located in an MSA & $\begin{array}{l}.017^{5} \\
(.007)\end{array}$ & $\begin{array}{r}.012^{1} \\
(.008)\end{array}$ & $\begin{array}{c}.013^{10} \\
(.007)\end{array}$ & $\begin{array}{l}.017^{10} \\
(.007)\end{array}$ & $\begin{array}{c}.019^{1} \\
(.007)\end{array}$ \\
\hline \multicolumn{6}{|l|}{ Price of trade credit } \\
\hline $\begin{array}{l}\text { Percent of credit purchases offered } \\
\text { with early payment discounts }\end{array}$ & & & & & $\begin{array}{l}.006 \\
(.011)\end{array}$ \\
\hline
\end{tabular}


Early payment discounts missing

\begin{tabular}{lccccc}
\hline Number of observations & 1968 & 1588 & 1968 & 1968 & 1968 \\
$\mathrm{R}^{2}$ & 14.9 & 0.2 & 17.6 & 15.3 & 15.6 \\
\hline \hline
\end{tabular}

Low asset values also caused some of the independent variables to be skewed. When the distribution of a variable was highly skewed, we recoded the upper percent of values to the 99th percentile of the distribution. These variables include purchase on account to assets, operating profits to assets, employees to assets, and number of trade creditors to assets.

${ }^{a}$ Predicted trade credit supply is the estimated value of purchase on account over assets from Table V, column I. We adjusted our estimate of purchases on account by subtracting off 0.200 (the coefficient on employment over assets) times the value of employment over assets for each observation. This removed the mismeasurement in purchases on account caused by wages being included in cost of goods sold, but not purchases on account.

${ }^{\mathrm{b}}$ This regression was estimated with instrumental variables. In addition to the other variables in the regression, we used employees per thousand dollars of assets, whether the firm was incorporated, and the percent of inventory which is finished goods as instruments. These are the variables which we used in Table V to estimate trade credit supply.

${ }^{\mathrm{c}}$ This regression includes 36 industry dummies -- one for each 2 digit SIC code in our data set.

${ }^{1}$ Coefficient significantly different from zero at the one percent level.

${ }^{5}$ Coefficient significantly different from zero at the five percent level.

${ }^{10}$ Coefficient significantly different from zero at the ten percent level. 
Figure 1: The Trade Credit Relationships

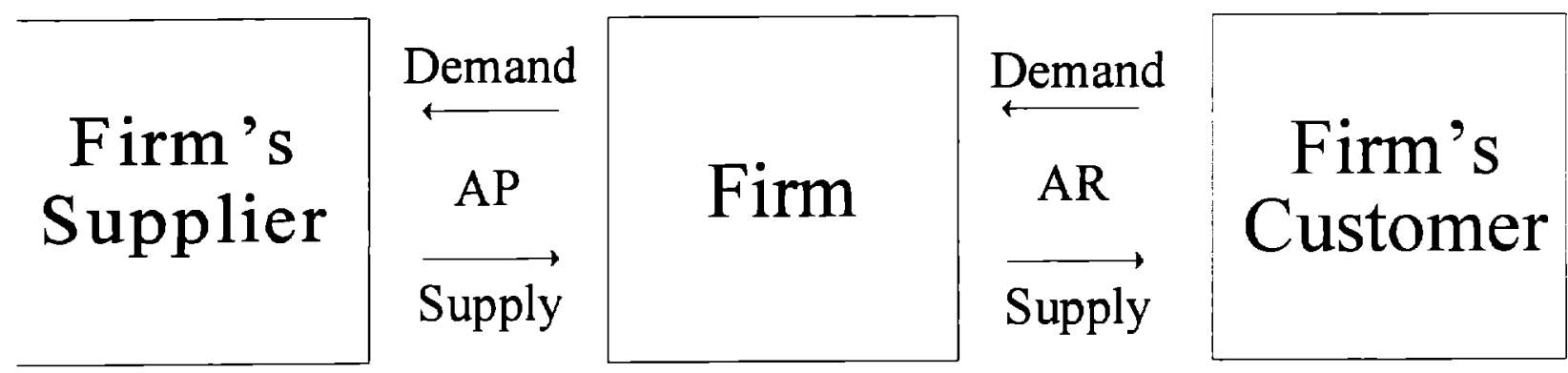

The amount of trade credit extended between the firm and its suppliers will appear as the accounts payable on the balance sheet of the firm. The amount of trade credit extended between the firm and its customers will appear as accounts receivable on the balance sheet of the firm. 